\title{
Optimization Method for Developmental Scheme to Ultra-low Permeability Reservoir
}

\author{
Gongquan Li and Yiliang Di \\ Yangtze University, Wuhan, China 430100
}

\begin{abstract}
In view of problems existing in ultra-low permeability reservoir development process, Honghe 55 well block in Zhenjing oil-field is selected as the research target. Based on its geological characteristics, a geological model was established to simulate the key problems such as length and orientation of horizontal well segment, reasonable well pattern arrangement, well spacing, and row gaps. Its developing policy can be determined from the simulation results. The length of horizontal well segment should be in 800-1000 meters. The orientation of horizontal well is perpendicular to the principal direction of stress. Nine-spot mixed well pattern, that is, horizontal well as production and vertical well as injection is adopted. $600 \mathrm{~m}$ spacing, row gaps between the 200 meters to 250 meters is the best.
\end{abstract}

Keywords-Ultra-low permeability reservoir; horizontal well; well pattern; numerical simulation

\section{INTRODUCTION}

There are common characteristics as low formation pressure, low energy, low natural production in ultra-low permeability reservoir, generally requires hydraulic fracturing in order to obtain industrial oil flow [1]. Strong heterogeneity and micro- cracks are the typical features in ultra-low permeability reservoir so that well pattern is very important [2]. Horizontal wells can communicate more cracks and reduce the pressure drop around the wellbore so as to establish effective displacement pressure. So it is widely used in the development to ultra-low permeability sandstone reservoir [3-5]. Reasonable layout of well pattern is the key to successful development of this type of oilfield. For the horizontal wells, its characteristics and rules is different from the conventional development with vertical well pattern. Patterns with the only horizontal wells, or horizontal wells and vertical wells, all are needed to make further research on well pattern and its parameters in order to understand development characteristics of well pattern and the dynamic influence of its parameters [6].

\section{A. Geological Settings}

Honghe 55 block in Zhenjing oilfield, located in Jingchuan County of Gansu Province, is one of the blocks in progressive exploration and development. The main oil-bearing stratum is Chang 9 oil-group in Yanchang Formation, Triassic. Reservoir buried depth is $1850-2150 \mathrm{~m}$ and it is mainly controlled by lithology factor. Front facies of braided river delta is main sedimentary environment. Three types of micro-facies can be identified including water distributary channel, mouth bar, distributary Bay .Distributary channel is the major depositional micro-facies in Chang 9 oil-group. The main sand body of
Chang 9 oil-group is formed by stacked setting of multi-stage underwater distributary channel. Reservoir thickness is 8.6$13.7 \mathrm{~m}$ and the average effective thickness is $10.7 \mathrm{~m}$. Its porosity is mainly distributed in the range of $5 \%-18 \%$, Unimodal distribution on the most widely interval of $14 \%-18 \%$ with an average of $13.4 \%$. Permeability is mainly distributed interval is $0.05-14.9 \mathrm{mD}$, presented a decreasing distribution, the average is $1.37 \mathrm{mD}$.

According to the analysis of Honghe 55 well, Honghe 42 well and Honghe 26 well, it is low sulfur light crude oil with its density of $0.8524 \mathrm{~g} / \mathrm{cm} 3$, the viscosity of $7.87 \mathrm{mPa} . \mathrm{s}$, the wax content of $14.3 \%$, the freezing point of $18{ }^{\circ} \mathrm{C}$. Its formation water is neutral chloride calcium type with the chloride ion content of $39752.9 \mathrm{mg} / \mathrm{L}$, the salinity of $63505.5 \mathrm{mg} / \mathrm{L}$.The result of Honghe 42 well DST shows that the original formation pressure is $18.25 \mathrm{MPa}(1783 \mathrm{~m})$, pressure coefficient is 1.02, the middle depth strata temperature is $63{ }^{\circ} \mathrm{C}$ (1783.00m), temperature is $2.86{ }^{\circ} \mathrm{C} / 100 \mathrm{~m}$.

According to the geological research of Honghe 55 block, its structure is smooth, average sand thickness is great. The condition of development with horizontal well is satisfied. So its development technical policy is needed to study.

\section{DEVElopment TECHNICAL POLICY}

A theory reservoir model should be built before applying numerical simulation method. According to the geological knowledge about Honghe 55 Block, the reservoir model is composed of 16000 grid cells with 80 in X direction and 200 in $\mathrm{Y}$ direction. The space in $\mathrm{X}$ and $\mathrm{Y}$ direction is $10 \mathrm{~m}$. Porosity is $13 \%$ and permeability is $2 \mathrm{mD}$. Relative permeability curve and PVT is the actual data of Honghe 55 Bock.

\section{A. Optimization of Horizontal Section Length}

Cumulative production were calculated on each condition of $500,600,700,800,900,1000,1100 \mathrm{~m}$ and $1200 \mathrm{~m}$ of horizontal section length as well as the constant bottom hole flowing pressure. Computing time is 2400 days. Cumulative oil production increases with the increase of horizontal section length. But increasing velocity of cumulative oil production is becoming slower when the horizontal length increases to $1000 \mathrm{~m}$. Therefore, the optimal length of horizontal section should be controlled at 800 - 1000m (Figure I). 


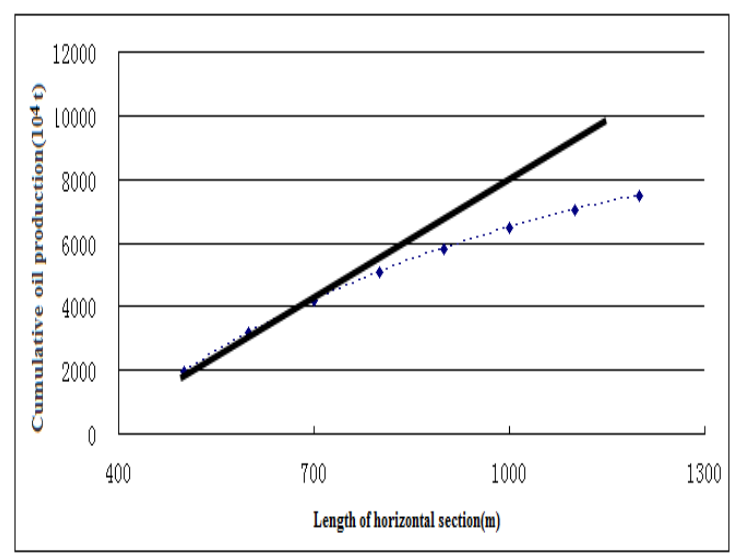

FIGURE I. RELATIONSHIP BETWEEN CUMULATIVE PRODUCTION AND HORIZONTAL SECTION LENGTH

\section{B. Extending direction of Horizontal Section}

Especially for ultra-low permeability reservoir, extension direction of the horizontal well in the reservoir is relative to fracture direction. The fracture is often associated with stress. Generally, direction of fracture is along the direction of maximum principal stress. There is a close relationship among structure style, reservoir sedimentary types and extension direction of horizontal section. Direction of horizontal section should be parallel to the tectonic line, perpendicular to the direction of edge water invasion in order to prevent the coning of injection water. The actual statistical data also show that there are much more difficulties in trajectory control, edge water tongued advance if horizontal section is perpendicular to the structure lines.

Based on the above factors, the direction angle between the horizontal well and the maximum principal stress is designed as $30^{\circ}, 45^{\circ}, 60^{\circ}, 75^{\circ}$, and $90^{\circ}$ (Figure II). According to the simulation results, recovery degree decreases gradually with the reduction of the angle when the horizontal direction is perpendicular to the direction of principal stress. So the optimal design direction of horizontal wells is perpendicular to the direction of the principal stress.

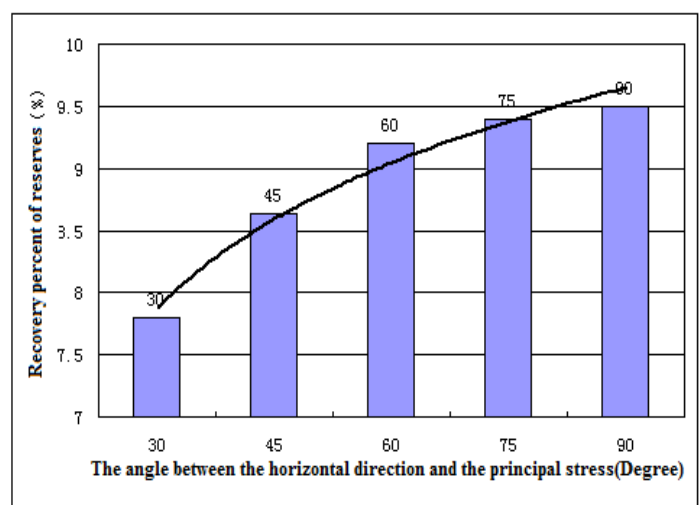

FIGURE II. DEVELOPMENTAL EFFECT ON DIFFERENT ANGLE BETWEEN HORIZONTALORIENTATION AND PRINCIPAL STRESS

\section{Optimization of Well Patterns}

Horizontal wells are chosen as production wells because of the prominent advantages of its production. Type of injecting wells should be determined by the results of numerical simulation. According to the heterogeneity characteristic of reservoir, injection-production well patterns are designed to predict development indexes and ultimate recovery through the numerical simulation. The reasonable injection-production well pattern is determined and the effects of dynamic developmental parameters are comprehensive evaluated.

There are many well patterns commonly used in the development of low permeability reservoir such as five-spot well pattern, nine-spot well pattern, inverted nine-spot well pattern, and so on[7-9]. Vertical well is more flexible to control the direction of injected water but injection pressure may be high. Through horizontal injected wells may reduce injection pressure, increase injection quantity, sweep efficiency is effected on more parameters, such as mobility ratio, well spacing, et al. So five-spot well pattern, nine-spot well and inverted nine-spot pattern are designed on the condition of horizontal wells as production wells.

A local area of 3D real geological model of Honghe 55 Block is chosen to coarsen that its mesh size is $50 \mathrm{~m} \times 50 \mathrm{~m}, 72$ $\times 78 \times 4=22464$ grid cells. Well patterns are designed on the basis of the horizontal well pattern design principle, adaptability of reservoir, and injection-production well ratio between vertical well and horizontal well. A total of 9 design scheme is provided (Figure III, Table I).

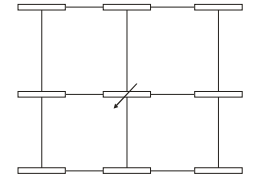

Scheme 1: Inverted nine-spot horizontal wells

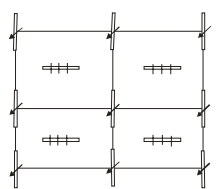

Scheme 4: Five-spot Horizontal Wells

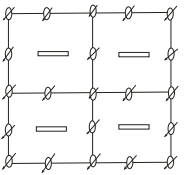

Scheme 7: Ninemixed well pattern

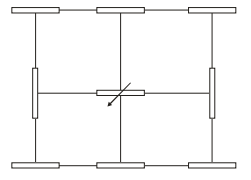

Scheme 2: Inverted nine-spot horizontal wells

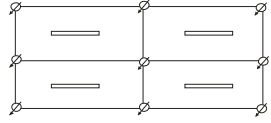

Scheme 5: Five-mixed well pattern

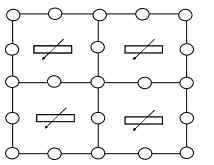

Scheme 8: Inverted Nine-spot Mixed Horizontal Wells

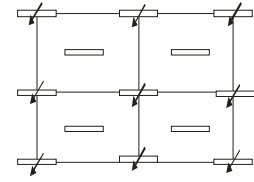

Scheme 3: Five-spo Horizontal Wells

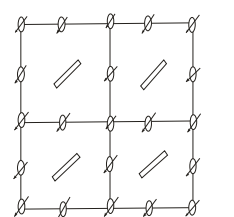

Scheme 6: Ninemixed well pattern

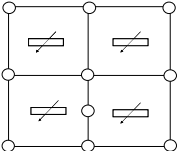

Scheme 9: Five-spot Mixed Well Pattern
FIGURE III. SIMULATING SCHEMES WITH WELL PATTERNS 
TABLE I. DEPLOYMENT OF THE BASIC WELL PATTERN

\begin{tabular}{|c|c|c|}
\hline Scheme & Well Patterns & Scheme description \\
\hline Scheme 1 & Inverted Nine-spot Horizontal Wells & Horizontal wells as production and injection, the same direction \\
\hline Scheme 2 & Inverted Nine-spot Horizontal Wells & $\begin{array}{c}\text { Horizontal wells as production and injection, Injection of Horizontal } \\
\text { section perpendicular to production }\end{array}$ \\
\hline Scheme 3 & Five-spot Horizontal Wells $\begin{array}{c}\text { Horizontal wells as production and injection, the direction paralleling } \\
\text { to the fracture }\end{array}$ \\
\hline Scheme 4 & Five-spot Horizontal Wells & Horizontal wells as production and injection \\
\hline Scheme 5 & Five-spot Mixed well pattern & Vertical wells as injection, Horizontal wells as production \\
\hline Scheme 6 & Nine-spot Mixed well pattern & $\begin{array}{c}\text { Vertical wells as injection, Horizontal wells as production, Horizontal } \\
\text { section paralleling to the diagonal line }\end{array}$ \\
\hline Scheme 7 & Nine-spot Mixed well pattern & $\begin{array}{c}\text { Vertical wells as injection } \text { Horizontal wells as production, Horizontal } \\
\text { section paralleling to the border }\end{array}$ \\
\hline Scheme 8 & Inverted Nine-spot Mixed Horizontal Wells & $\begin{array}{c}\text { Vertical wells as production, Horizontal wells as injection, Horizontal } \\
\text { section paralleling to the edge }\end{array}$ \\
\hline Scheme 9 & Five-spot Mixed Well Pattern & Vertical wells as production, Horizontal wells as injection \\
\hline
\end{tabular}

Development indexes of each well pattern is obtained by numerical simulation (Figure IV and figure V) .The result shows that Scheme 6 and 7 are the best in development effect which Scheme 6 is slightly higher than Scheme 7. That is, ninemixed well pattern, vertical well as injection and horizontal well as production, can get the better effect. Scheme 5, fivemixed well pattern vertical well as injection and horizontal well as production, can get the better effect. Scheme 9, that is, fivespot well pattern of horizontal well as injection of vertical well as production is the worst for development effect. Mixed well patterns are higher than development effect of horizontal wells as injection and production. So development effect of ninemixed well pattern is the best.
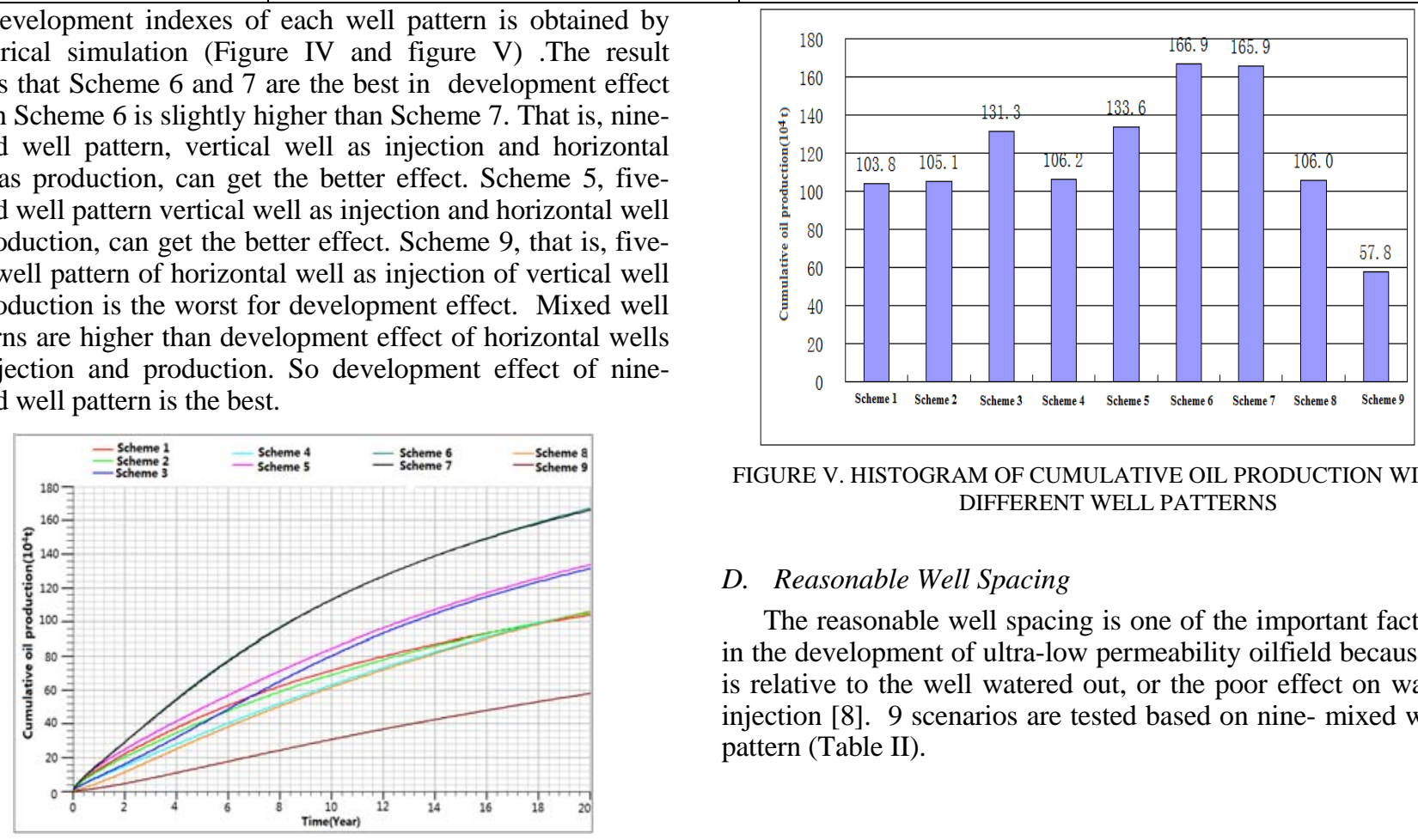

FIGURE V. HISTOGRAM OF CUMULATIVE OIL PRODUCTION WITH DIFFERENT WELL PATTERNS

\section{Reasonable Well Spacing}

The reasonable well spacing is one of the important factors in the development of ultra-low permeability oilfield because it is relative to the well watered out, or the poor effect on water injection [8]. 9 scenarios are tested based on nine- mixed well pattern (Table II).

FIGURE IV. CUMULATIVE OIL PRODUCTION CURVES OF DIFFERENT WELL PATTERNS

TABLE II. DESIGN TABLE WITH ROW, COLUMN SPACING BETWEEN WELLS

\begin{tabular}{|c|c|c|c|c|c|c|}
\hline Schemas & Well Spacing/m & Row Spacing/m & Horizontal section /m & Well Patterns & $\begin{array}{c}\text { Sum of Horizontal } \\
\text { Wells } \\
\end{array}$ & Sum of Vertical Wells \\
\hline Schema 2 & 600 & 250 & 800 & Nine-mixed well pattern & 18 & 73 \\
\hline Schema 3 & 700 & 250 & 800 & Nine-mixed well pattern & 18 & 60 \\
\hline Schema 4 & 800 & 250 & 800 & Nine-mixed well pattern & 12 & 52 \\
\hline Schema 5 & 600 & 200 & 800 & Nine-mixed well pattern & 24 & 95 \\
\hline Schema 6 & 600 & 300 & 800 & Nine-mixed well pattern & 15 & 62 \\
\hline Schema 7 & 600 & 350 & 800 & Nine-mixed well pattern & 15 & 55 \\
\hline Schema 8 & 600 & 400 & 800 & Nine-mixed well pattern & 12 & 51 \\
\hline Schema 9 & 600 & 150 & 800 & Nine-mixed well pattern & 33 & 128 \\
\hline
\end{tabular}


The development indexes from simulation to each scheme show that cumulated oil production of Scheme 2 is the highest and cumulative oil production of Scheme 4 is the worst when row spacing is constant $250 \mathrm{~m}$ (Figure VI), that is, $600 \mathrm{~m}$ well spacing is the best effect and $800 \mathrm{~m}$ well spacing is the worst. When well spacing is constant $600 \mathrm{~m}$, Scheme 5 is the highest, followed by Scheme 2 and Scheme 9. With row spacing decreases, cumulative oil recovery gradually become larger, but when the effect of row spacing of $150 \mathrm{~m}$ is worse (Figure VII). Therefore, the optimal row spacing should be among 200 - 250m.

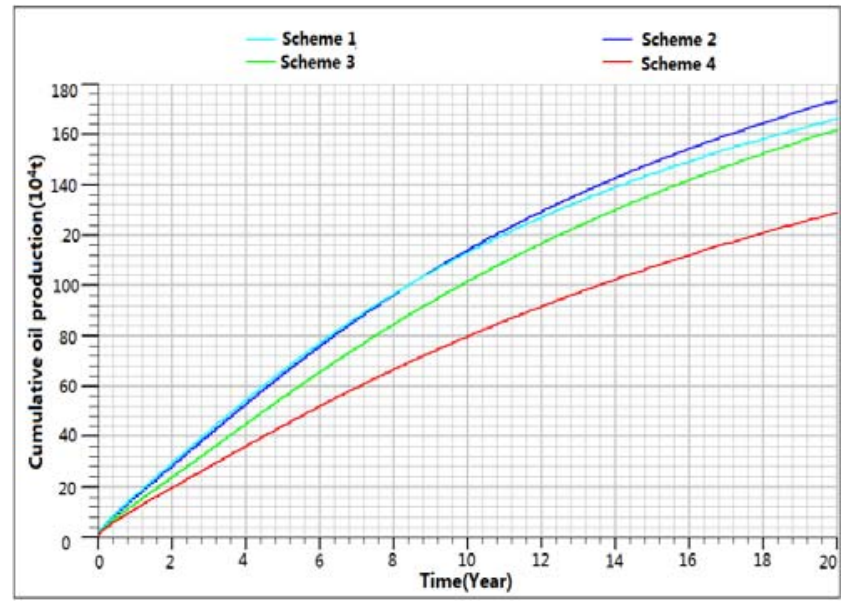

FIGURE VI. CUMULATIVE OIL PRODUCTION CURVES WITH DIFFERENT WELL SPACING

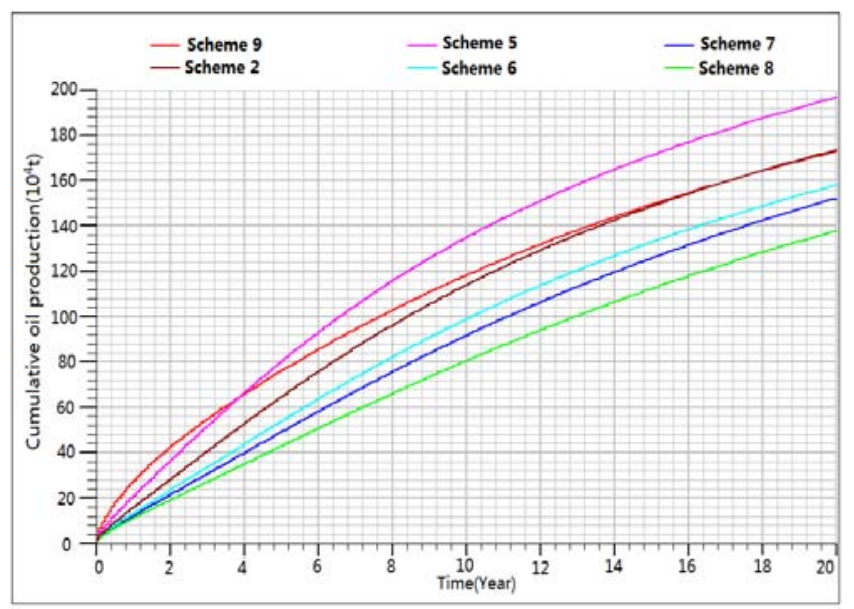

FIGURE VII. CUMULATIVE OIL PRODUCTION CURVES WITH DIFFERENT ROW SPACING

\section{DISCUSSION}

According to the real geological settings, a theoretical reservoir model is built to optimize the parameters of horizontal well including its direction and its length of horizontal section and well patterns. Results from numerical simulation method are concluded as following:

(1) Reasonable length of horizontal section may be among the range to $800 \sim 1000 \mathrm{~m}$; and the direction of horizontal section is NE that is perpendicular to the principal stress direction.
(2) Nine-mixed well pattern is suitable for Honghe 55 Block, vertical well as injection, horizontal well as production.

(3) Rational well spacing is $600 \mathrm{~m}$; row spacing is among 200-250m.

\section{REFERENCE}

[1] Gatens J M, Lee W J. The effects of permeability anisotropy on the evaluation and design of hydraulic fracture treatments and well performance [A].SPE 21501, 1991,211-222.

[2] LIU Dehua, LI Shilun, WU Jun. Concept of Vector Well Pattern and Method of Well Pattern Arrangement [J]. JOURNAL OF JIANGHAN PETROLEUM INSTITUTE, 2004, 26(1): 110 -111.

[3]YANG Yong, SU Haifang, HOU Zhongwu, et al. Developing lowpermeability sandstone reservoirs using horizontal well [J]. PETROLEUM GEOLOGY AND RECOVERY EFFICIENCY, 2002, 9(2): 23-25.

[4] RAN Xinquan, CHENG Qigui, QU Xuefeng, et al. Study on horizontal well pattern in ultra-low permeability sandstone reservoir [J]. ACTA PETROLEI SINICA, 2008, 29(1): 92 - 99.

[5]LIU Pengfei, JIANG Hanqiao, JIANG Zhen, et al. Adaptability of water flooding with horizontal wells in low permeability reservoirs [J].SPECIAL OIL \& GAS RESERVOIRS, 2009, 16(3):7-9.

[6] Tagwa Ahmed Musa, Ahmed Abd Elaziz lbrahin, Guan Zhen Liang, et al. Optimization of Field Development Scheduling, East Unity Oil Field, Sudan. American Journal of Environmental Sciences [J], 2005, 1 (1): 2933.

[7] SHI Chengen, LI Jian, LEI Qihong, et al. Research and practice on wellpattern type of ultra-low permeability oil field [J]. Petroleum Exploration \& Development, 2002, 29(5):59-61.

[8]SUI Xianfu,Wu Xiaodong, AN Yongsheng, et al. Appropriate horizontal pattern configuration optimization in low permeability reservoir[J]. Oil Drilling \& Production Technology, 2009, 31(6):100-103.

[9] ZHAN Xue-wen, Fang Hongchang, Qi Mei. A design of optimal well pattern for the development of low permeability reservoirs [J].Petroleum Exploration and Development, 2000, 27(3): 57-59. 